\title{
Pemodelan 3 Dimensi Candi Wringinlawang Menggunakan Metode Structure From Motion untuk Dokumentasi Cagar Budaya
}

\author{
Selfi Naufatunnisa dan Agung Budi Cahyono. \\ Departemen Teknik Geomatika, Fakultas Teknik Sipil dan Perencanaan, Institut Teknologi Sepuluh Nopember (ITS) \\ e-mail: agungbc@geodesy.its.ac.id
}

\begin{abstract}
Abstrak-Candi Wringinlawang merupakan salah satu cagar budaya peninggalan kerajaan Majapahit yang bertempat di Kabupaten Mojokerto, Jawa Timur. Dengan riwayat pemugaran terakhir pada tahun 1991/1992 s.d. 1994/1995, perlu dilakukan pendokumentasian sesuai dengan UU no 11 tahun 2010 tentang Cagar Budaya. Seiring berkembangnya teknologi, penelitian untuk mendapatkan bentuk 3D banyak dilakukan seperti pengaplikasian Structure from Motion (SfM) dalam pendokumentasian cagar budaya. Karena untuk keperluan dokumentasi, diperlukan model 3D yang sudah bergeoreference dengan akurasi kurang dari $0.5 \mathrm{~m}$ sesuai dengan syarat bangunan dengan LoD 3. Penggunaan kamera non metrik Sony Exmor 12.4 $M$ yang dibantu dengan wahana DJI Phantom 3 dalam pengambilan foto candi menghasilkan 155 buah foto, 465,487 titik sparse cloud, 5,996,415 titik dense cloud, 1,155,740 faces, dan $\mathbf{5 8 0 , 1 4 7}$ vertices. Setelah dilakukan analisa menggunakan titik ICP lapangan, didapatkan besar $\mathrm{RMSEx}=0.042 \mathrm{~m}, \mathrm{RMSEy}=0.047 \mathrm{~m}$, RMSEz $=0.048 \mathrm{~m}$.
\end{abstract}

Kata Kunci-Candi Wringinlawang, Structure From Motion (SfM), model 3D.

\section{PENDAHULUAN}

$\mathrm{K}^{\mathrm{n}}$ EKAYAAN akan budaya di Indonesia dapat ditunjukkan dengan banyaknya situs budaya sebagai bukti peninggalan dari kerajaan-kerajaan terdahulu. Candi Wringinlawang merupakan salah satu dari sekian banyak bukti peninggalan dari kerajaan Majapahit yang sekarang berlokasi di Kabupaten Mojokerto. Dinamakan Candi Wringinlawang karena berasal dari bahasa Jawa yakni wringin berarti pohon beringin dan lawang berarti pintu. Candi Wringinlawang telah dipugar dua kali pada Tahun 1991/1992 s.d. 1994/1995 [1].

Seiring berkembangnya teknologi, penelitian untuk mendapatkan bentuk 3D sesuai penglihatan mata manusia banyak dilakukan. Bidang penelitian ini dikenal dengan nama computer vision [2]. Salah satunya perkembangan dari computer vision adalah Structure from Motion (SfM) yang merupakan pendekatan untuk sekumpulan gambar dengan tingkat overlap tinggi yang didapat dari sensor bergerak sehingga dapat menangkap struktur 3 dimensi secara keseluruhan lokasi dan dari berbagai posisi [3].

Penelitian tentang computer vision telah diterapkan dalam upaya dokumentasi cagar budaya di Indonesia seperti Candi Singosari [4][5], Candi Borobudur [6], Candi Brahu [7]. Pada penelitian Candi Singosari telah menerapkan metode Structure from Motion dan menghasilkan ketelitian model 3D yang memiliki tidak jauh berbeda dengan data Terrestrial Laser Scanning (TLS). Di penelitian sebelumnya yakni Candi Singosari [4][5], sisi atas candi tidak tergambar karena terbatasnya alat dalam pengambilan gambar. Oleh karena itu pada penelitian ini, kamera Sony Exmor akan dibawa wahana quadcopter DJI Phantom 3 untuk memudahkan pengambilan gambar bagian atas candi.

Dengan bentuk candi yang menyerupai gapura dengan ukuran $13 \times 11.5 \mathrm{~m}$ dan tinggi $15.50 \mathrm{~m}$ [8], sampai saat ini belum ada penelitian tentang dokumentasi bentuk 3D candi. Beberapa penelitian yang dilakukan di Candi Wringinlawang hanya dari segi artistik dan sejarah [9], mengingat candi ini diduga sebagai pintu masuk menuju bangunan penting di ibukota Majapahit.

Sehingga tujuan dari penelitian ini adalah mendokumentasikan bentuk Candi Wringinlawang dengan pemodelan 3D yang sudah georeference menggunakan metode Structure from Motion (SfM). Model 3D yang dihasilkan memiliki tingkat Level of Detail (LoD) 3 dimana akurasi yang diperbolehkan sebesar $0.5 \mathrm{~m}$. Manfaat penelitian ini adalah sebagai upaya pendokumentasian situs budaya di Indonesia sesuai dengan pasal 53 ayat 4 UU no 11 tahun 2010 tentang Cagar Budaya.

\section{METODOLOGI PENELITIAN}

\section{A. Lokasi Penelitian}

Lokasi penelitian berada pada koordinat $-7.5410693^{\circ} \mathrm{LS}$, $112.3879172^{\circ}$ BT yakni bertempat di Candi Wringinlawang, Kabupaten Mojokerto. 


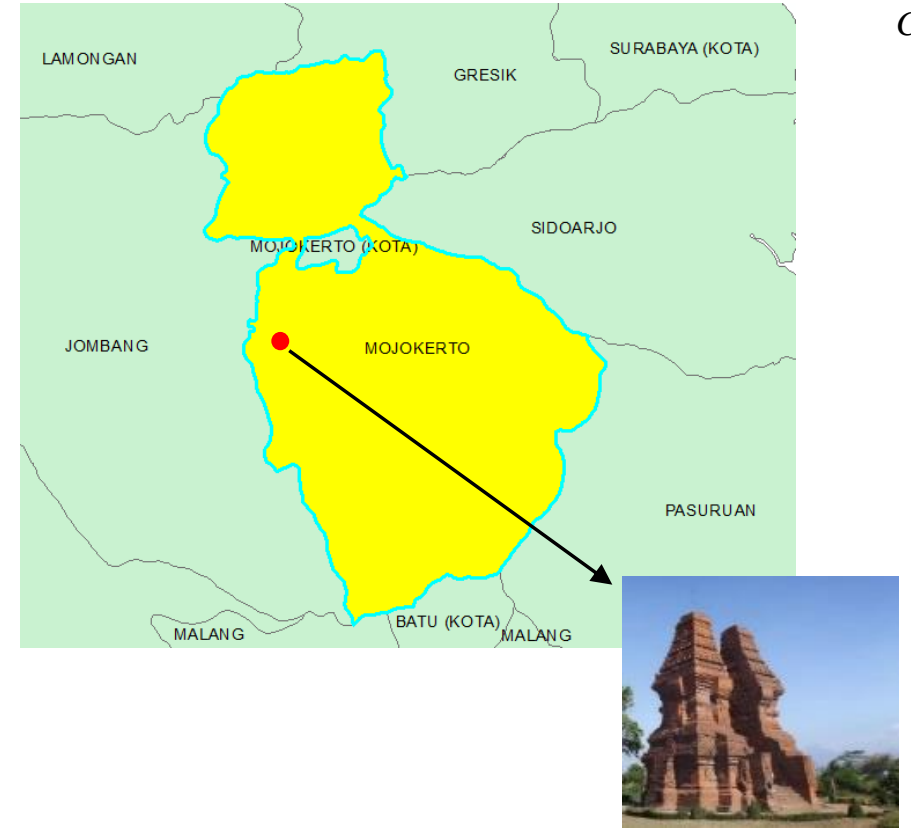

Gambar 1. Lokasi Penelitian

\section{B. Data dan Peralatan}

\section{1) Data}

Data pendukung penelitian seperti berikut :

1. Foto Candi Wringinlawang dari berbagai sisi yang diambil menggunakan kamera Sony Exmor

2. Koordinat $(\mathrm{x}, \mathrm{y}, \mathrm{z})$ titik kontrol sebagai data acuan georeference

3. Koordinat $(\mathrm{x}, \mathrm{y}, \mathrm{z})$ titik cek sebagai pembanding dalam analisa ketelitian geometrik model yang dihasilkan

\section{2) Peralatan}

Peralatan yang digunakan pada penelitian ini meliputi:

1. Perangkat Keras

- Kamera non-metrik Sony Exmor 12.4 M

- Drone DJI Phantom 3 sebagai wahana kamera

- Total Station Reflectorless Hi-Target

- 2 set GPS Geodetic Topcon Hiper-Pro

- Personal Computer (PC)

Windows 7 Ultimate

Precessor Intel (R) Core (TM) i5-4460 CPU @3.20

GHz; RAM 8.00 GB; 64-bit OS

- Marker

\section{3) Perangkat Lunak}

- Software Office untuk pembuatan laporan dan pengolahan data

- Software pengolah foto untuk pembuatan model 3D
C.Tahapan Pengolahan Data

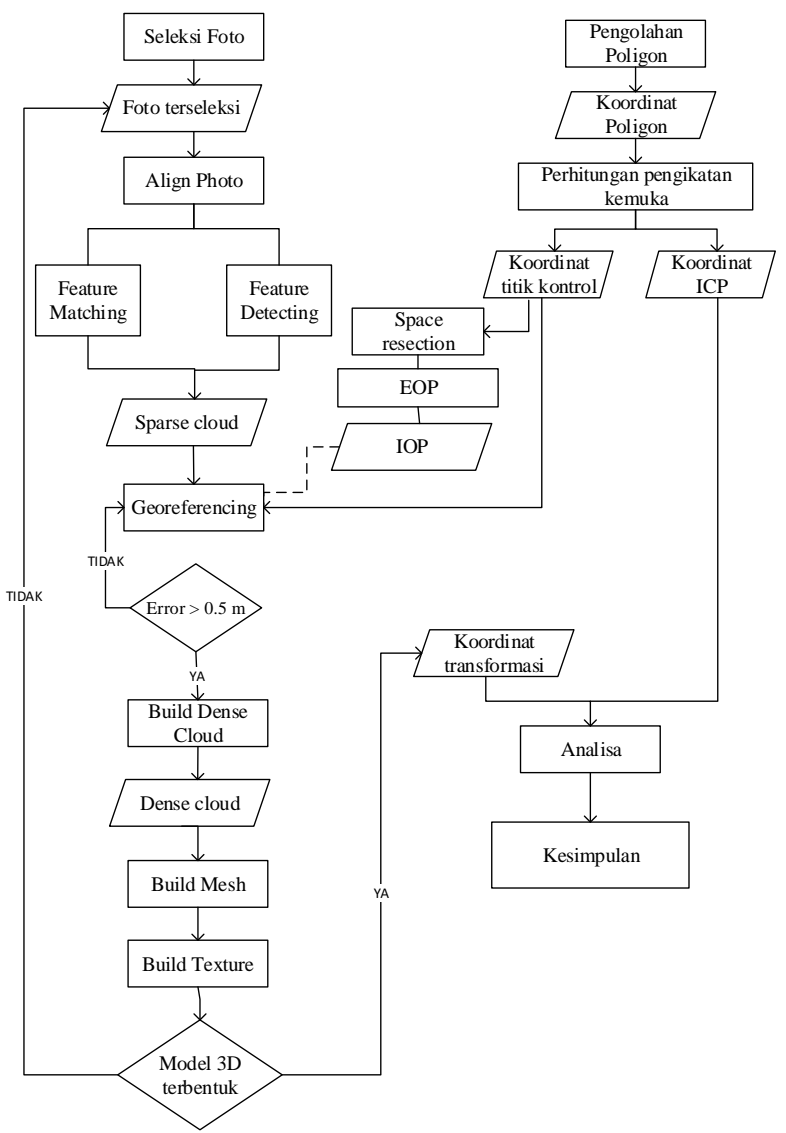

Gambar 2. Diagram Alir Pengolahan Data

Penjelasan diagram alir di atas sebagai berikut :

1. Pengumpulan Data

Pengumpulan data foto menggunakan kamera nonmetrik Sony Exmor 12.4 M serta pengukuran titik GCP dan ICP.

2. Pengolahan Foto

Pemrosesan foto meliputi feature detecting dan feature matching (menggunakan algorithma SIFT), pembentukan mesh, pemberian tekstur.

3. Georeferencing

Proses georeferencing model 3D dengan koordinat $\mathrm{x}, \mathrm{y}, \mathrm{z}$ yang didapatkan dari pengukuran lapangan. Dikarenakan hasil pemodelan adalah LoD 3, maka toleransi yang diberikan sebesar $0.5 \mathrm{~m}$.

4. Kalibrasi Kamera

Pada penelitian ini kalibrasi kamera menggunakan algorithma Bundle Adjustment Self Callibration. Pada tahap kalibrasi, IOP yang didapat adalah panjang lensa(f), titik eksposure foto (xo,yo), distorsi radial (p1, $\mathrm{p} 2)$ dan distorsi tangensial $(\mathrm{k} 1, \mathrm{k} 2, \mathrm{k} 3)$.

$x_{a}-x_{o}+\Delta x=-f \frac{\left(r_{11}\left(X_{A}-X_{L}\right)+r_{21}\left(Y_{A}-Y_{L}\right)+r_{31}\left(Z_{A}-Z_{L}\right)\right)}{\left(r_{13}\left(X_{A}-X_{L}\right)+r_{23}\left(Y_{A}-Y_{L}\right)+r_{33}\left(Z_{A}-Z_{L}\right)\right)}$
$y_{a}-y_{o}+\Delta y=-f \frac{\left(r_{12}\left(X_{A}-X_{L}\right)+r_{22}\left(Y_{A}-Y_{L}\right)+r_{23}\left(Z_{A}-Z_{L}\right)\right)}{\left(r_{13}\left(X_{A}-X_{L}\right)+r_{23}\left(Y_{A}-Y_{L}\right)+r_{33}\left(Z Z_{A}-Z_{L}\right)\right)}$

Dimana :

$\Delta x, \Delta y$ merupakan kesalahan sistematik dari gambar yang berupa fungsi dari koordinat foto untuk 
menghasilkan distorsi lensa khususnya di kamera digital.

5. Analisa

Analisa yang dilakukan bertujuan untuk mengetahui ketelitian model yang dihasilkan.

- Uji probability standar error (95\%) dilakukan untuk mengevaluasi hasil pengukuran berdasarkan pada standar deviasi.

$\mathrm{E}_{95}=1.960 \sigma$

- RMSE (Root Mean Square) dilakukan untuk mengetahui akurasi prediksi bacaan.

$$
\begin{aligned}
& \text { RMSE } X=\sqrt{\frac{\sum_{i=1}^{n}\left(x_{\text {foto }}-x_{T S}\right)^{2}}{n}} \\
& \text { RMSE } Y=\sqrt{\frac{\sum_{i=1}^{n}\left(Y_{\text {foto }}-Y_{T S}\right)^{2}}{n}} \\
& \text { RMSE } Z=\sqrt{\frac{\sum_{i=1}^{n}\left(Z_{\text {foto }}-Z_{T S}\right)^{2}}{n}}
\end{aligned}
$$

Keterangan :

$x_{\text {foto }} Y_{\text {foto }} Z_{\text {foto }}=$ nilai prediksi ke $-\mathrm{i}$

$x_{T S} Y_{T S} Z_{T S}=$ nilai pengamatan ke-i

$\mathrm{n}=$ jumlah pengamatan

\section{HASIL DAN ANALISA}

\section{A. Kalibrasi Kamera}

Hasil kalibrasi kamera Bundle Adjustment self calibration seperti berikut :

Tabel 1.

Tabel hasil kalibrasi

\begin{tabular}{crr}
\hline \hline Jenis foto & \multicolumn{1}{c}{ Foto Miring } & \multicolumn{1}{c}{ Foto Tegak } \\
\hline Ukuran foto & $4000 \times 2250 \mathrm{pix}$ & $4000 \times 3000 \mathrm{pix}$ \\
fx & $3.935 \mathrm{~mm}$ & $3.514 \mathrm{~mm}$ \\
fy & $3.987 \mathrm{~mm}$ & $3.586 \mathrm{~mm}$ \\
xo & $3.396 \mathrm{~mm}$ & $3.147 \mathrm{~mm}$ \\
yo & $1.867 \mathrm{~mm}$ & $2.293 \mathrm{~mm}$ \\
k1 & 0.00000442 & -0.00000055 \\
k2 & -0.00010448 & -0.00004442 \\
k3 & 0.00020151 & 0.00008495 \\
p1 & -0.00000122 & -0.00000245 \\
p2 & -0.00000025 & 0.00000445 \\
\hline \hline
\end{tabular}

Tabel di atas menggambarkan jika kamera yang digunakan yakni Sony Exmor yang dibawa drone tidak stabil. Selain karena kamera tersebut bukan kamera metrik yang tidak memiliki ketetapan dalam parameter kamera, besar distorsi juga dapat dipengaruhi cara pengambilan fotonya yang miring dan tegak.

\section{B. Kerangka Poligon, Titik Kontrol, dan ICP}

Tabel 2.

Tabel Koordinat Poligon

\begin{tabular}{llcc}
\hline \hline Nama Titik & $\mathrm{X}(\mathrm{m})$ & $\mathrm{Y}(\mathrm{m})$ & $\mathrm{Z}(\mathrm{m})$ \\
\hline GCP1 & 653443.367 & 9166100.262 & 71.125 \\
GCP2 & 653482.558 & 9166112.998 & 71.587 \\
GCP3 & 653487.170 & 9166075.060 & 71.611 \\
GCP4 & 653477.437 & 9166062.339 & 71.592 \\
\hline \hline
\end{tabular}

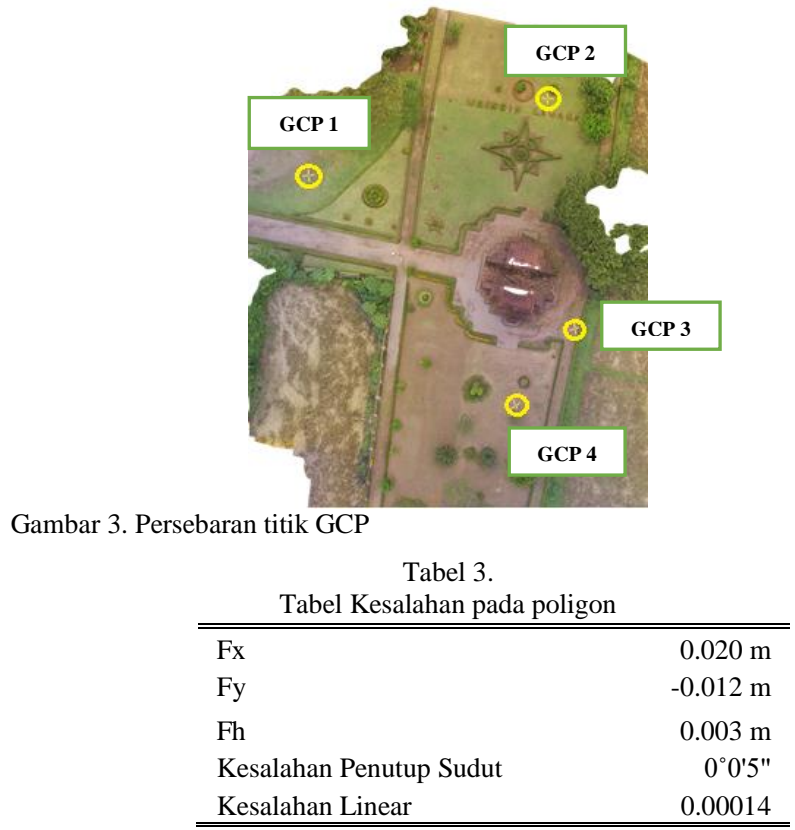

Total Station yang digunakan memiliki bacaan terkecil 1" dengan toleransi $1 " \sqrt{n}=1 " \sqrt{4}=2$ ". Sehingga kesalahan penutup sudut poligon pengukuran tidak masuk toleransi. Hal ini dapat disebabkan karena prisma yang digunakan sebagai target tidak tegak lurus dengan patok yang terpasang.

Untuk kesalahan linier, toleransi yang diperbolehkan sebesar 1/2500 (atau 0.0004). Pada penelitian ini memiliki kesalahan linier 0.00014 atau $1 / 714.285$, sehingga masih masuk batas toleransi.

Tabel 4.

Titik Kontrol pada Candi

\begin{tabular}{rlccc}
\hline \hline No & Nama Titik & $\mathrm{X}(\mathrm{m})$ & $\mathrm{Y}(\mathrm{m})$ & $\mathrm{Z}(\mathrm{m})$ \\
\hline 1 & DPN1 & 653477.410 & 9166085.060 & 86.783 \\
2 & DPN9 & 653472.753 & 9166086.042 & 75.077 \\
3 & KR4 & 653480.388 & 9166079.552 & 80.845 \\
4 & KR9 & 653481.240 & 9166084.315 & 80.808 \\
\hline \hline
\end{tabular}

\begin{tabular}{|c|c|c|c|c|c|c|c|}
\hline \multirow{2}{*}{ No } & \multirow{2}{*}{$\begin{array}{l}\text { Nama } \\
\text { Titik }\end{array}$} & \multicolumn{3}{|c|}{ Pengukuran di Lapangan } & \multicolumn{3}{|c|}{ Model 3D } \\
\hline & & $\mathrm{X}(\mathrm{m})$ & $\mathrm{Y}(\mathrm{m})$ & $\mathrm{Z}(\mathrm{m})$ & ) & $\mathrm{Y}(\mathrm{m})$ & $Z(\mathrm{~m})$ \\
\hline 1 & PN2 & 5347 & 92 & 86.941 & 77.9545 & 9166086.628 & 86.883 \\
\hline 2 & & 1 & & 86.8 & 6534 & 94 & 86.841 \\
\hline 3 & DPN4 & 3476 & & 86.944 & 653476 & & 86.91 \\
\hline 4 & & & & & & & 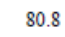 \\
\hline 5 & DP & 98 & & 80.885 & 69 & 51 & 80.837 \\
\hline 6 & & & & 75. & & & \\
\hline 7 & & & & 3 & & & \\
\hline 8 & DPN14 & 3 & 91 & 72.611 & 537 & & 72.636 \\
\hline 9 & & & & & & & \\
\hline 10 & & & & & & & 80.861 \\
\hline 11 & $\mathrm{KR} 3$ & 5 & 916 & 80.872 & 653 & 01 & 80.863 \\
\hline 12 & $\mathrm{KR} 5$ & & & & & 91 & 72.706 \\
\hline 13 & $\mathrm{KR} 6$ & & 916 & 72.644 & & & 72.716 \\
\hline 14 & & & & & & & \\
\hline 15 & BKLG5 & 653481.612 & 9166078.121 & 75.156 & 653481.638 & 9166078.102 & 75.075 \\
\hline 16 & BKLG6 & 653483.334 & 9166086.562 & 75.127 & 653483.2782 & 9166086.618 & 75.035 \\
\hline 17 & & 653479.477 & 9166086.277 & 87.004 & 653479.5162 & 9166086.338 & 86.9 \\
\hline 18 & $\mathrm{aNN} 3$ & 653480.297 & 9166088.289 & 80.814 & 653480.3098 & 9166088.395 & 80.795 \\
\hline
\end{tabular}

Tabel 5.

Tabel Koordinat ICP dari pengukuran Lapangan 


\section{Lanjutan tabel 5}

\begin{tabular}{cccccccc}
\hline \multirow{2}{*}{ No } & \multirow{2}{*}{$\begin{array}{c}\text { Nama } \\
\text { Titik }\end{array}$} & \multicolumn{3}{c}{ Pengukuran di Lapangan } & \multicolumn{3}{c}{ Model 3D } \\
\cline { 3 - 8 } & & $\mathrm{X}(\mathrm{m})$ & $\mathrm{Y}(\mathrm{m})$ & $\mathrm{Z}(\mathrm{m})$ & $\mathrm{X}(\mathrm{m})$ & $\mathrm{Y}(\mathrm{m})$ & $\mathrm{Z}(\mathrm{m})$ \\
\hline 20 & KNN5 & 653481.483 & 9166085.746 & 80.815 & 653481.5275 & 9166085.795 & 80.785 \\
21 & KNN6 & 653483.214 & 9166086.517 & 72.632 & 653483.2584 & 9166086.525 & 72.669 \\
22 & KNN7 & 653482.177 & 9166088.165 & 73.14 & 653482.2128 & 9166088.15 & 73.164 \\
\hline
\end{tabular}
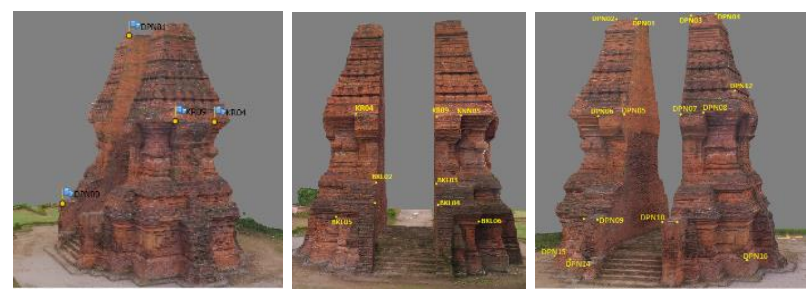

Gambar 4. (ki-ka) persebaran titik kontrol candi, persebaran titik ICP bagian timur; ICP bagian barat

\section{Model 3D}

\section{1) Foto Objek}

Foto objek yang digunakan dalam pengolahan ini sebanyak 155 buah foto dengan metode pengambilan menjadi foto tegak dan foto miring. Berikut ini sampel foto objek Candi Wringinlawang yang diambil dengan kamera Sony EXMOR dibantu wahana quadcopter DJI Phantom 3 :
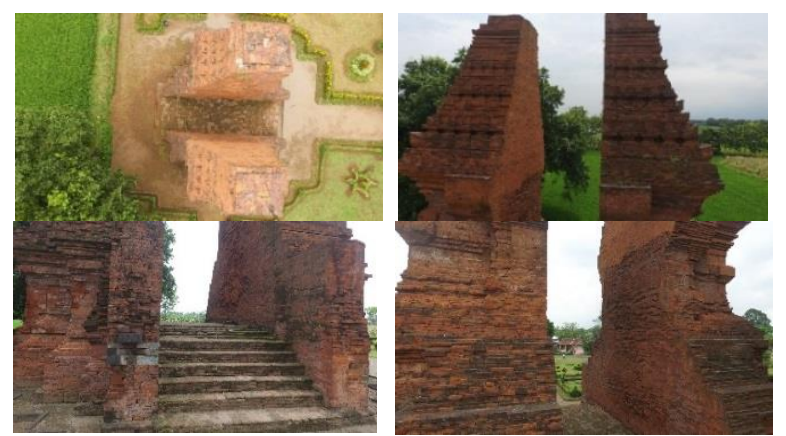

Gambar 5. Sampel Pengambilan Foto (kiri-kanan, atas-bawah): foto tegak Candi, foto miring bagian atas candi, foto miring bagian bawah candi, foto miring bagian tengah candi.

Berikut ini merupakan hasil dari pengolahan SfM :

Tabel 6.

Hasil Pengolahan SfM

\begin{tabular}{ll}
\multicolumn{2}{c}{ Hasil Pengolahan SfM } \\
\hline \hline Total Foto & 155 buah \\
Sparse cloud & 465,487 point \\
Dense cloud & $5,996,415$ point \\
& $1,155,740$ faces, \\
Textured & 580,147 vertices \\
\hline \hline
\end{tabular}

\section{2) Posisi Kamera}

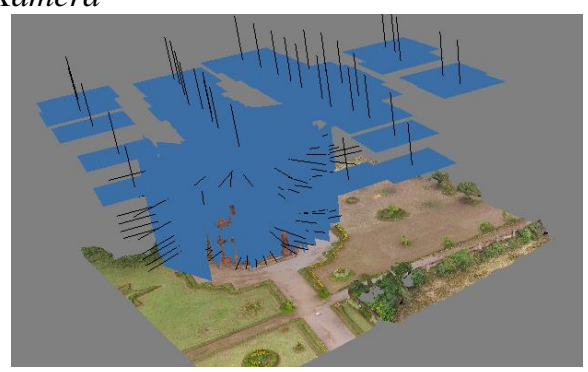

Gambar 6. Sisi pengambilan Gambar

\section{3) Alignment Photo}

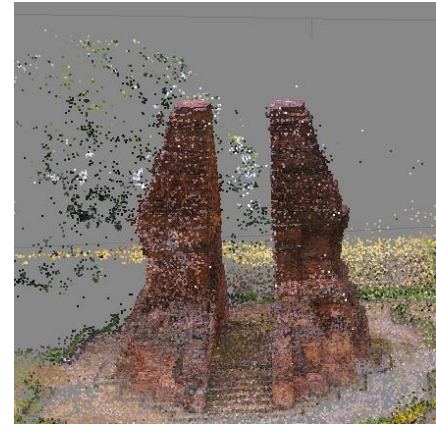

Gambar 7. Hasil Alignment Photo

4) Build Dense Cloud

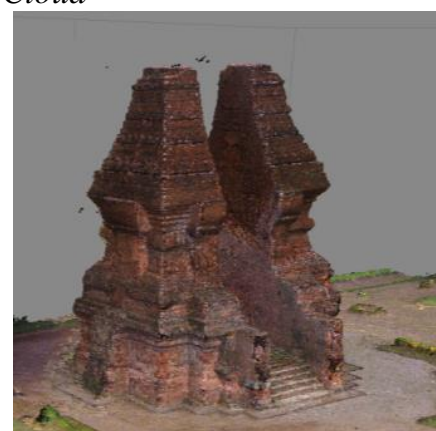

Gambar 8. Hasil Build Dense Cloud

5) Build Mesh

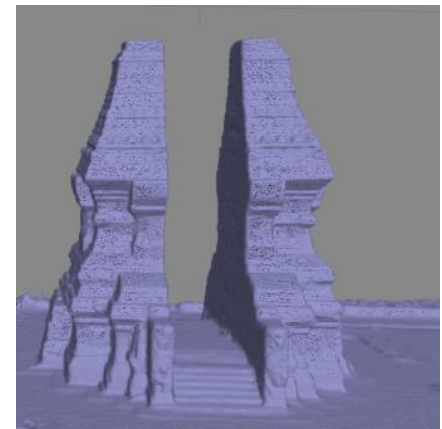

Gambar 9. Hasil Build Mesh

6) Model 3D Candi Wringinlawang
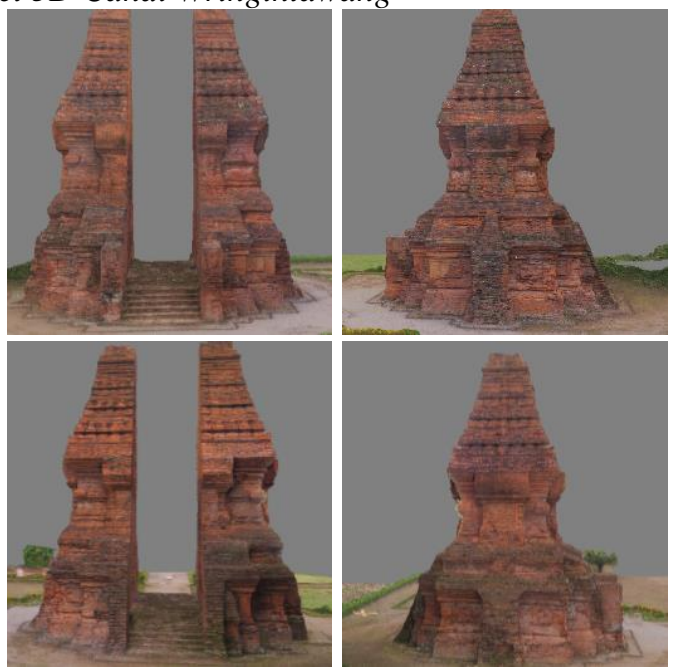

Gambar 10. Model 3D tampak depan, kiri,belakang,kanan 


\section{D.Analisa}

\section{1) Koordinat $X$}

Koordinat X memiliki nilai standar deviasi sebesar $0.032 \mathrm{~m}$ dan nilai RMSE sebesar $0.042 \mathrm{~m}$. Untuk uji error probability pada selang kepercayaan $95 \%$ dimana nilai $\mathrm{E}_{95}=0.063 \mathrm{~m}$ selang kepercayaan -0.035 hingga $0.091 \mathrm{~m}$. Pada tabel 7, titik DPN 8 tidak diterima. Sehingga dari 22 data, terdapat 21 data diterima atau $95,45 \%$ dari seluruh data. Berikut kesalahan pada koordinat $\mathrm{X}$ :

Tabel 7.

Tabel Uji Eror Koordinat X

\begin{tabular}{|c|c|c|c|c|c|}
\hline \multirow[t]{2}{*}{ No } & \multirow{2}{*}{$\begin{array}{l}\text { Nama } \\
\text { Titik }\end{array}$} & \multirow{2}{*}{$\begin{array}{c}\begin{array}{c}\text { Pengukuran } \\
\text { Lapangan }\end{array} \\
\mathrm{X}(\mathrm{m}) \\
\end{array}$} & \multirow{2}{*}{$\begin{array}{r}\text { Model 3D } \\
\mathrm{X}(\mathrm{m})\end{array}$} & \multirow{2}{*}{$\begin{array}{l}\text { Error } \\
(\mathrm{m})\end{array}$} & \multirow[t]{2}{*}{ Ket } \\
\hline & & & & & \\
\hline 1 & DPN2 & 653477.946 & 653477.954 & 0.0083 & diterima \\
\hline 2 & DPN3 & 653476.771 & 653476.770 & 0.0009 & diterima \\
\hline 3 & DPN4 & 653476.711 & 653476.718 & 0.0065 & diterima \\
\hline 4 & DPN5 & 653475.436 & 653475.431 & 0.0053 & $\begin{array}{l}\text { diterima } \\
\text { tidak }\end{array}$ \\
\hline 5 & DPN8 & 653474.798 & 653474.647 & 0.1513 & diterima \\
\hline 6 & DPN10 & 653472.053 & 653472.016 & 0.0367 & diterima \\
\hline 7 & DPN12 & 653474.694 & 653474.693 & 0.0009 & diterima \\
\hline 8 & DPN14 & 653474.513 & 653474.553 & 0.0408 & diterima \\
\hline 9 & $\mathrm{KR} 1$ & 653478.196 & 653478.192 & 0.0039 & diterima \\
\hline 10 & $\mathrm{KR} 2$ & 653478.283 & 653478.270 & 0.0129 & diterima \\
\hline 11 & KR3 & 653475.845 & 653475.831 & 0.0141 & diterima \\
\hline 12 & KR5 & 653481.631 & 653481.637 & 0.0057 & diterima \\
\hline 13 & KR6 & 653480.246 & 653480.237 & 0.0093 & diterima \\
\hline 14 & BKLG3 & 653481.646 & 653481.671 & 0.0247 & diterima \\
\hline 15 & BKLG5 & 653481.612 & 653481.638 & 0.0261 & diterima \\
\hline 16 & BKLG6 & 653483.334 & 653483.278 & 0.0559 & diterima \\
\hline 17 & KNN2 & 653479.477 & 653479.516 & 0.0387 & diterima \\
\hline 18 & KNN3 & 653480.296 & 653480.309 & 0.0130 & diterima \\
\hline 19 & KNN4 & 653477.815 & 653477.8478 & 0.032868 & diterima \\
\hline 20 & KNN5 & 653481.483 & 653481.5275 & 0.044238 & diterima \\
\hline 21 & KNN6 & 653483.214 & 653483.2584 & 0.044536 & diterima \\
\hline 22 & KNN7 & 653482.177 & 653482.2128 & 0.035511 & diterima \\
\hline
\end{tabular}

\section{2) Koordinat $Y$}

Koordinat Y memiliki nilai standar deviasi sebesar $0.030 \mathrm{~m}$ dan nilai RMSE sebesar $0.047 \mathrm{~m}$. Untuk uji error probability pada selang kepercayaan $95 \%$ dimana nilai $E_{95}=0.059 \mathrm{~m}$ memiliki selang kepercayaan $-0.021 \mathrm{~m}$ hingga $0.096 \mathrm{~m}$. Pada tabel 8, titik KNN 3 tidak diterima. Sehingga dari 22 data, terdapat 21 data diterima atau 95,45\% dari seluruh data. Berikut kesalahan pada koordinat Y :

Tabel 8.

Tabel Uji Eror Koordinat Y

\begin{tabular}{cccccc}
\hline \hline No & $\begin{array}{c}\text { Nama } \\
\text { Titik }\end{array}$ & $\begin{array}{c}\text { Pengukuran } \\
\text { di Lapangan } \\
\text { Y }(\mathrm{m})\end{array}$ & Model 3D & $\begin{array}{c}\text { Error } \\
(\mathrm{m})\end{array}$ & Ket \\
\hline 1 & DPN2 & 9166086.592 & 9166086.628 & 0.0368 & diterima \\
2 & DPN3 & 9166081.786 & 9166081.794 & 0.0081 & diterima \\
3 & DPN4 & 9166080.165 & 9166080.159 & 0.0061 & diterima \\
4 & DPN5 & 9166085.449 & 9166085.451 & 0.0014 & diterima \\
5 & DPN8 & 9166080.562 & 9166080.651 & 0.0889 & diterima \\
\hline \multirow{5}{*}{ No } & Nama & Pengukuran & Model 3D & Error & Ket \\
& Titik & Lapangan & Y $(\mathrm{m})$ & diterima \\
\hline 6
\end{tabular}

\begin{tabular}{rlrrrl}
\hline 7 & DPN12 & 9166078.828 & 9166078.796 & 0.0318 & diterima \\
8 & DPN14 & 9166088.253 & 9166088.24 & 0.0133 & diterima \\
9 & KR1 & 9166079.876 & 9166079.888 & 0.0115 & diterima \\
10 & KR2 & 9166077.858 & 9166077.839 & 0.0189 & diterima \\
11 & KR3 & 9166078.158 & 9166078.101 & 0.0568 & diterima \\
12 & KR5 & 9166078.171 & 9166078.119 & 0.0519 & diterima \\
13 & KR6 & 9166076.839 & 9166076.784 & 0.0552 & diterima \\
14 & BKLG3 & 9166084.247 & 9166084.264 & 0.0171 & diterima \\
15 & BKLG5 & 9166078.121 & 9166078.102 & 0.0193 & diterima \\
16 & BKLG6 & 9166086.562 & 9166086.618 & 0.0561 & diterima \\
17 & KNN2 & 9166086.277 & 9166086.338 & 0.0609 & diterima \\
& & & & & Tidak \\
18 & KNN3 & 9166088.289 & 9166088.395 & 0.1059 & diterima \\
19 & KNN4 & 9166088.770 & 9166088.859 & 0.0890 & diterima \\
20 & KNN5 & 9166085.746 & 9166085.795 & 0.0494 & diterima \\
21 & KNN6 & 9166086.517 & 9166086.525 & 0.0084 & diterima \\
22 & KNN7 & 9166088.165 & 9166088.150 & 0.0152 & diterima \\
\hline \hline
\end{tabular}

\section{3) Koordinat $Z$}

Koordinat Z memiliki nilai standar deviasi sebesar $0.026 \mathrm{~m}$ dan nilai RMSE sebesar $0.048 \mathrm{~m}$. Untuk uji error probability dengan tingkat kepercayaan $95 \%$ dimana nilai $\mathrm{E}_{95}=0.052 \mathrm{~m}$, memiliki selang kepercayaan $-0.018 \mathrm{~m}$ hingga $0.093 \mathrm{~m}$. Pada tabel di bawah, semua titik diterima dalam selang kepercayaan, sehingga $100 \%$ data dipercaya. Berikut kesalahan pada koordinat $\mathrm{Z}$ :

Tabel 9.

Tabel Uji Eror Koordinat Z

\begin{tabular}{|c|c|c|c|c|c|}
\hline No & $\begin{array}{c}\text { Nama } \\
\text { Titik }\end{array}$ & $\begin{array}{c}\text { Pengukuran } \\
\text { Lapangan } \\
\text { Z (m) }\end{array}$ & $\begin{array}{c}\text { Model 3D } \\
\text { Z (m) }\end{array}$ & $\begin{array}{l}\text { Error } \\
(\mathrm{m})\end{array}$ & Ket \\
\hline 1 & DPN2 & 86.941 & 86.883 & 0.058 & diterima \\
\hline 4 & DPN5 & 80.813 & 80.799 & 0.013 & diterima \\
\hline 5 & DPN8 & 80.885 & 80.837 & 0.048 & diterima \\
\hline 6 & DPN10 & 75.086 & 75.115 & 0.029 & diterima \\
\hline 7 & DPN12 & 82.093 & 82.095 & 0.002 & diterima \\
\hline 8 & DPN14 & 72.610 & 72.636 & 0.025 & diterima \\
\hline 9 & KR1 & 87.005 & 86.976 & 0.029 & diterima \\
\hline 10 & KR2 & 80.952 & 80.861 & 0.091 & diterima \\
\hline 11 & KR3 & 80.872 & 80.862 & 0.009 & diterima \\
\hline 12 & KR5 & 72.635 & 72.705 & 0.071 & diterima \\
\hline 13 & KR6 & 72.643 & 72.716 & 0.073 & diterima \\
\hline 14 & BKLG3 & 76.707 & 76.719 & 0.012 & diterima \\
\hline 15 & BKLG5 & 75.155 & 75.075 & 0.081 & diterima \\
\hline 16 & BKLG6 & 75.127 & 75.035 & 0.092 & diterima \\
\hline 17 & KNN2 & 87.004 & 86.947 & 0.057 & diterima \\
\hline 18 & KNN3 & 80.814 & 80.794 & 0.019 & diterima \\
\hline 19 & KNN4 & 80.820 & 80.795 & 0.024 & diterima \\
\hline 20 & KNN5 & 80.815 & 80.785 & 0.029 & diterima \\
\hline 21 & KNN6 & 72.632 & 72.669 & 0.037 & diterima \\
\hline 22 & KNN7 & 73.140 & 73.164 & 0.023 & diterima \\
\hline
\end{tabular}




\section{KESIMPULAN}

Pada penelitian ini, kesimpulan yang dapat diambil sebagai berikut :

1. Model 3D Candi Wringinlawang terbentuk dari 155 buah foto dan terdiri atas 465,487 titik sparse cloud, 5,996,415 titik dense cloud, serta 1,155,740 faces dan 580,147 vertex.

2. Bentuk model 3D Candi Wringinlawang termasuk dalam LoD3 ditunjukkan oleh penampakan eksterior candi yang menyerupai objek sebenarnya (pada gambar 10) serta nilai RMSE kurang dari $0.5 \mathrm{~m}$. Berikut ini nilai RMSE koordinat model 3D :

- Koordinat $X$ dengan RMSEx $=0.042 \mathrm{~m}$

- Koordinat $Y$ dengan RMSEy $=0.047 \mathrm{~m}$

- Koordinat $\mathrm{Z}$ dengan $\mathrm{RMSEz}=0.048 \mathrm{~m}$

3. Untuk mengevaluasi kesalahan dilakukan uji probability error pada selang kepercayaan 95\%. Berikut hasil uji probability error:

- Koordinat $X$ dengan $\mathrm{dx}=0.032 \mathrm{~m}$ terdapat 21 titik diterima

- Koordinat $\mathrm{Y}$ dengan $\mathrm{dy}=0.030 \mathrm{~m}$ terdapat 21 titik diterima

- Koordinat $\mathrm{Z}$ dengan $\mathrm{dz}=0.032 \mathrm{~m}$ terdapat 22 titik diterima

\section{UCAPAN TERIMAKASIH}

Penulis S. N. mengucapkan terimakasih kepada kantor BPCB Jawa Timur selaku pengurus Candi Wringinlawang atas izinnya, serta tim PVIA (Photogrammetry Vision and Image Analysis) Teknik Geomatika ITS.

\section{DAFTAR PUSTAKA}

[1] S. M. Wardani, L. K; Sitindjak, R. H. I; Sari, "Estetika Ragam Hias Candi Bentar dan Panduraksa di Jawa Timur," in Konferensi Nasional Pengkajian Seni (Arts and Beyong), 2015.

[2] R. Szeliski, "Computer Vision: Algorithms and Applications," Springer, 2010.

[3] M. J. dkk Westoby, "Structure-from-motion photogrammetry : a low cost, effective tool for geoscience applications," pp. 300-314, 2012.

[4] A. B. Hidayat, H dan Cahyono, "3D Reconstruction of Singosari Temple Using Terrestrial Images and Structure From Motion Algorithm," ICOIRS, 2015.

[5] H. H. Putra, A. R dan Handayani, "3D Modelling Using Structure From Motion And Terrestrial Laser Scanning (Case Study : Singosari Temple, Malang)," Institut Teknologi Sepuluh Nopember, 2016.

[6] D. dkk Suwardhi, "Digital 3D Borobudur: Integration of 3D Surveying and Modeling Techniques.," Int. Arch. Photogramm. Remote Sens. Spat. Inf. Sci., vol. XL-5/W7, 2015.

[7] H. H. Salam, M. S dan Handayani, "emanfaatan Fotogrametri Rentang Dekat untuk Pemodelan 3D Cagar Budaya Menggunakan Kamera Non-metrik (Studi Kasus: Candi Brahu, Mojokerto)," Res. Gate, 2016.

[8] P. RI, "Deskripsi Jawa Timur - Candi Wringin Lawang (http://candi.perpusnas.go.id/temples/deskripsi-jawa_timurcandi_wringinlawang),, 2016 . .

[9] D. Kurniasih, "Kajian Historis Candi Wringin Lawang di Desa Jatipasar Kecamatan Trowulan Kabupaten Mojokerto sebagai Pintu Masuk Sebuah Komplek Bangunan," Universitas Nusantara PGRI, 2015. 